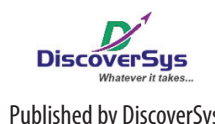

Published by DiscoverSys

\title{
Delayed access to treatment and frequency of acute respiratory infection as risk factors of severe pneumonia among children aged 12-59 months in Denpasar, Bali
}

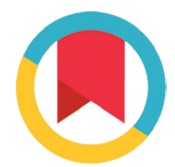

CrossMark

\author{
Dewa Ayu Ketut Sri Abadi, ${ }^{*}$ Dewa Nyoman Wirawan, ${ }^{2}$ Anak Agung Sagung Sawitri, ${ }^{2}$ \\ I Gusti Ayu Trisna Windiani ${ }^{3}$
}

\section{ABSTRACT}

Background and purpose: Period prevalence of pneumonia among children in Indonesia increased from 2.1 in 2007 to 2.7 per 1000 children in 2013. The highest incidence was found among children aged 12-23 months. This study aims to examine association between delayed access to health care facilities and severity of children pneumonia. Methods: A case control study was conducted in Denpasar City. A total of 132 children were recruited to participate in this study, consisted of 44 cases and 88 controls. Cases were selected from 161 children with severe pneumonia who registered at Pulmonology Department of Sanglah General Hospital between January 2015 and April 2016. Controls were selected from 261 children aged 12-59 months with mild pneumonia who visited out-patient service at all community health centres in Denpasar City between January 2015 and April 2016. Cases and controls were matched by sex. Data were collected by interview with the parents in their houses. Data were analysed using multivariate analysis with logistic regression.

Results: Risk factors associated to severity of pneumonia among children aged 12-59 months were delayed access to treatment for more than three days ( $\mathrm{AOR}=2.15 ; 95 \% \mathrm{Cl}: 1.39-3.32)$, non-health care facilities at first episode of illness ( $A O R=4.02 ; 95 \% \mathrm{Cl}$ : 1.53-10.61) and frequent episodes of respiratory infections ( $>4$ times) over the last 6 months ( $A O R=5.45 ; 95 \% \mathrm{Cl}: 2.13-13.96)$.

Conclusion: Delayed access to treatment, did not access healthcare facilities at first episode of illness, and high frequency of acute respiratory infections are risk factors of severe pneumonia among children.
'Bali Province Health Office, ${ }^{2}$ Public Health Postgraduate Program Udayana University, ${ }^{3}$ Department of Paediatric Faculty of Medicine Udayana University/ Sanglah General Hospital Denpasar

*Correspondence to: Dewa Ayu Ketut Sri Abadi, Bali Province Health Office dewaayusriabadi@yahoo.com
Key words: children, severe pneumonia, delayed treatment, case control, Bali

Cite This Article: Abadi, D.A.K.S., Wirawan, D.N., Sawitri, A.A.S., Windiani, I.G.A.T. 2017. Delayed access to treatment and frequency of acute respiratory infection as risk factors of severe pneumonia among children aged 12-59 months in Denpasar, Bali. Public Health and Preventive Medicine Archive 5(1): 61-66. D0l:10.15562/phpma.v5i1.45

\section{INTRODUCTION}

Globally, pneumonia has killed more children than HIV/AIDS, malaria, and measles - where $19 \%$ of children mortality was due to pneumonia. ${ }^{1}$ In Indonesia, pneumonia is the second cause of mortality among children after diarrhoea as many as $15.5 \%$ children mortality was due to pneumonia. ${ }^{2}$ The 2013 Basic Health Survey (Riskesdas) showed that the period prevalence of pneumonia among children increased from 2.1 per 1000 children in 2007 to 2.7 per 1000 children in 2013. ${ }^{3}$ The highest incidence was found among children aged 12-23 months (21.7\%). ${ }^{3}$ The 2014 Health Profile of Bali Province indicated that the main cause of children mortality was acute respiratory infections, including pneumonia. Over the last three years, the reported cases of acute respiratory infections including pneumonia was increasing and was ranked fourth out of 10 most common diseases among children in Bali Province. ${ }^{4}$
Studies regarding risk factors of severe pneumonia have been conducted in many areas, however still very limited in Indonesia. ${ }^{5,6,7}$ Published articles globally showed that comorbidity illness, delayed access to treatment, disease frequency over the last six months, and contact history with family members who suffer from respiratory infections are identified as risk factors of severe pneumonia. ${ }^{8,9}$

Sanglah General Hospital Denpasar is one of the referral tertiary hospitals for East Indonesia. Data from Pulmonology Unit of Paediatric Department of Sanglah Hospital showed that there were 189 severe pneumonia cases in 2014, 120 cases in 2015 and 133 cases in 2016. The majority of severe pneumonia cases were referred by community health centres or district hospitals and also families who directly access services from Sanglah Hospital. This study aims to examine association between delayed access to healthcare 
facilities, frequency of acute respiratory diseases over the last six months and severity of pneumonia among children.

\section{METHODS}

A case control study was conducted in Denpasar City. A total of 132 children were recruited to participate in the study, consisted of 44 cases and 88 controls. Cases were children aged 12-59 months who had diagnosed with severe pneumonia based on the 2013 WHO criteria. ${ }^{10}$ Cases were selected from a total of 283 children with severe pneumonia between January 2015 and April 2016 who registered at the Pulmonology Unit, Department of Paediatric Faculty of Medicine Udayana University/Sanglah General Hospital Denpasar. Exclusion criteria for cases included: children with severe pneumonia who stay outside of Denpasar City, no address available at the medical record, aged $>5$ years, aged $<1$ years, children with major congenital diseases, and children with genetic diseases. From 283 children in the register, there were 161 potential cases visited, the rest were excluded due to incomplete address. From 161 children, 48 were not found because of incorrect address, two children passed away, 62 families moved to unknown address, and five refused to participate in the study. A total of 44 cases were identified and all were included in the study. Controls were children aged 12-59 months who had been diagnosed with pneumonia by medical doctor at the community health centre based on the pneumonia management module developed by the Ministry of Health of Indonesia 2015. Out of 261 children with pneumonia recorded at the patient register book of 11 community health centres in Denpasar City between January 2015 to April 2016, incomplete addresses were found among 112 children, 32 children moved to another area, and two passed away. From the remaining eligible control of 118 children, 88 children were randomly selected as controls. Cases and controls were matched by sex.

Data on risk factors were obtained by interview using a structured questionnaire at the parents' houses between April to June 2016. Data included delayed access to healthcare facilities, did not access health services at first episode of illness, frequency of illness over the last six months, age, immunization record, low birth weight, nutritional status, exclusive breastfeeding status, education level of mother, knowledge level of mother, employment status, smoke exposure from kitchen and smoking, family income, house density, access to clean water and diseases comorbidity.
Several questions were asked to assess level of knowledge of mothers on pneumonia, which included: causes, signs, transmission routes, prevention strategies, time to access health care services, benefits of colostrum, benefit of immunization and hand washing. Delayed access to healthcare services was measured as total days from onset of pneumonia and the day when the children was presented to healthcare services. Choice of health care for the first episode of illness was classified as health care facility and non-healthcare facilities. Non-healthcare facilities included not seeking treatment, self-medication using non-prescribed medicines, and self-medication using traditional medicines. Frequency of illness in the last six months was defined as total illnesses experienced by children which included common cold, fever, and cough over the last six months. Data on immunization status, birth weight, weight at the diagnosis, and age were obtained from the medical record. Nutritional status was measured based on children weight and age.

Data were analysed using chi square test to screen variables for multivariate analysis. All variables with $p$ value $<0.25$ were included in the multivariate analysis using logistic regression to calculate adjusted odd ratio (AOR). This study protocol has been approved by the Human Research Ethics Committees of Faculty of Medicine Udayana University/Sanglah General Hospital Denpasar.

\section{RESULTS}

Table 1 shows comparison between cases and 161 potential cases in terms of age, sex, nutritional status, birth weight, exclusive breastfeeding, immunization status, frequency of illnesses, education level of mother, and employment status of mother. There was no significant difference between cases and potential cases. Comparison between controls and all out-patients with mild pneumonia accessing services at community health centres cannot be made due to incomplete data available at the medical record at the health centres.

Table 2 shows comparison between cases and controls. Cases and controls were comparable in terms of children age, birth weight, immunization status, nutritional status, education level of mother, level of knowledge, family income, house density, and access to clean water. Several variables significantly differed between cases and controls included exclusive breastfeeding ( $\mathrm{p}=0.033)$, smoke exposure from kitchen and smoking inside the house $(p=0.032)$, accessing healthcare facilities $(p<0.0001)$, utilizing referral healthcare facilities $(p<0.001)$, frequency of illnesses of more 
Table 1 Comparison between cases and all severe pneumonia patients at Sanglah Hospital

\begin{tabular}{|c|c|c|c|}
\hline & Potential cases $(n=161)$ & Cases $(n=44)$ & \\
\hline Variables & $f(\%)$ & $f(\%)$ & p value \\
\hline \multicolumn{4}{|l|}{ Sex } \\
\hline Female & $76(47.2)$ & $24(54.5)$ & 0.389 \\
\hline Male & $85(52.8)$ & $20(45.5)$ & \\
\hline \multicolumn{4}{|l|}{ Children age } \\
\hline 25-59 month & $53(32.9)$ & $14(31.8)$ & 0.890 \\
\hline 12-24 month & $108(67.1)$ & $30(68.2)$ & \\
\hline \multicolumn{4}{|l|}{ Address } \\
\hline North Denpasar & $57(35.4)$ & $16(36.4)$ & 0.800 \\
\hline West Denpasar & $35(21.7)$ & $11(25.0)$ & 0.678 \\
\hline South Denpasar & $47(29.2)$ & $11(25.0)$ & 0.957 \\
\hline East Denpasar & $22(13.7)$ & $6(13.6)$ & \\
\hline \multicolumn{4}{|l|}{ Nutritional Status } \\
\hline Good & $111(68.9)$ & $33(75.0)$ & 0.437 \\
\hline Poor & $50(31.1)$ & $11(25.0)$ & \\
\hline \multicolumn{4}{|l|}{ Birth weight } \\
\hline Normal & $149(92.5)$ & $39(88.6)$ & 0.408 \\
\hline Low & $12(7.5)$ & $5(11.4)$ & \\
\hline \multicolumn{4}{|l|}{ Mother's education level } \\
\hline Senior high-tertiary & $69(42.9)$ & $23(52.3)$ & 0.267 \\
\hline No school-junior high & $92(57.1)$ & $21(47.7)$ & \\
\hline \multicolumn{4}{|l|}{ Exclusive breastfeeding } \\
\hline Yes & $34(21.1)$ & $11(25.0)$ & 0.582 \\
\hline No & $127(78.9)$ & $33(75.0)$ & \\
\hline \multicolumn{4}{|l|}{ Immunisation status } \\
\hline Complete & $59(36.6)$ & $15(34.1)$ & 0.755 \\
\hline Incomplete & $102(63.4)$ & $29(65.9)$ & \\
\hline \multicolumn{4}{|l|}{ Mother's employment } \\
\hline Employed & $77(47.8)$ & $19(43.2)$ & 0.585 \\
\hline Not employed & $84(52.2)$ & $25(56.8)$ & \\
\hline \multicolumn{4}{|c|}{ Number of days before visiting health services } \\
\hline Mean \pm SD & $3.31 \pm 1.26$ & $3.27 \pm 1.32$ & 0.838 \\
\hline \multicolumn{4}{|c|}{ Health care at first episode of illness } \\
\hline Health care facilities & $67(41.6)$ & $21(47.7)$ & 0.468 \\
\hline Non-health care facilities & $94(58.4)$ & $23(52.3)$ & \\
\hline \multicolumn{4}{|l|}{ Frequency of illnesses } \\
\hline Low & $66(41.0)$ & $18(40.9)$ & 0.992 \\
\hline High & $95(59.0)$ & $26(59.1)$ & \\
\hline
\end{tabular}

than four times $(p=0.001)$, and delayed access to treatment $(\mathrm{p}<0.001)$. There were seven variables with $\mathrm{p}$-values $<0.25$ and all were included in the multivariate analysis as presented in Table 3. Multivariate analysis revealed that severity of pneumonia among children was associated with delayed access to healthcare facilities (AOR $=2.15$; 95\%CI: 1.39-3.32), children who did not access health services (AOR $=4.02$; 95\%CI: 1.53-10.61), and children with frequency of illnesses of more than four times over the last six months $(\mathrm{AOR}=5.45 ; 95 \% \mathrm{CI}$ : 2.13-13.96). 
Table 2 Crude OR and comparison between cases and controls

\begin{tabular}{|c|c|c|c|c|c|}
\hline Variables & Cases & Controls & Crude OR & $95 \% \mathrm{Cl}$ & p value \\
\hline \multicolumn{6}{|l|}{ Children age (months) } \\
\hline 25-59 month & $14(31.8)$ & $32(36.4)$ & 1.22 & $0.57-2.64$ & 0.606 \\
\hline $12-24$ month & $30(68.2)$ & $56(63.6)$ & & & \\
\hline \multicolumn{6}{|l|}{ Birth weight (gram) } \\
\hline Normal & $39(88.6)$ & $77(87.5)$ & 0.89 & $0.29-2.76$ & 0.850 \\
\hline Low & $5(11.4)$ & $11(12.5)$ & & & \\
\hline \multicolumn{6}{|l|}{ Immunisation status } \\
\hline Complete & $15(34.1)$ & $36(40.9)$ & 1.34 & $0.63-2.85$ & 0.449 \\
\hline Incomplete & $29(65.9)$ & $52(59.1)$ & & & \\
\hline \multicolumn{6}{|l|}{ Pentavalen immunisation } \\
\hline Complete & $28(63.6)$ & $50(56.8)$ & 0.75 & $0.36-1.58$ & 0.453 \\
\hline Incomplete & $16(36.4)$ & $38(43.2)$ & & & \\
\hline \multicolumn{6}{|l|}{ DPT immunisation } \\
\hline Complete & $24(54.5)$ & $49(55.7)$ & 1.05 & $0.51-2.17$ & 0.901 \\
\hline Incomplete & $20(45.5)$ & $39(44.3)$ & & & \\
\hline \multicolumn{6}{|l|}{ Measles immunisation } \\
\hline Complete & $40(90.9)$ & $86(97.7)$ & 4.29 & $0.76-24.46$ & 0.100 \\
\hline Incomplete & $4(9.1)$ & $2(2.3)$ & & & \\
\hline \multicolumn{6}{|l|}{ Nutritional status } \\
\hline Good & $33(75.0)$ & $68(77.3)$ & 1.13 & $0.49-2.64$ & 0.772 \\
\hline Poor & $11(25.0)$ & $20(22.7)$ & & & \\
\hline \multicolumn{6}{|l|}{ Exclusive breastfeeding } \\
\hline Yes & $11(25.0)$ & $39(44.3)$ & 2.39 & $1.07-5.32$ & 0.033 \\
\hline No & $33(75.0)$ & $49(55.7)$ & & & \\
\hline \multicolumn{6}{|l|}{ Mother's education level } \\
\hline Senior high-tertiary & $23(52.3)$ & $41(46.6)$ & 0.79 & $0.39-1.64$ & 0.538 \\
\hline No school-junior high & $21(47.7)$ & $47(53.4)$ & & & \\
\hline \multicolumn{6}{|l|}{ Mother's knowledge } \\
\hline Moderate & $17(38.6)$ & $32(36.4)$ & 0.91 & $0.43-1.91$ & 0.799 \\
\hline Low & $27(61.4)$ & $56(63.6)$ & & & \\
\hline \multicolumn{6}{|l|}{ Family income (rupiah) } \\
\hline$>1,800,000,-$ & $33(75.0)$ & $73(82.9)$ & 1.62 & $0.67-3.91$ & 0.281 \\
\hline$<1,800,000,-$ & $11(25.0)$ & $15(17.1)$ & & & \\
\hline \multicolumn{6}{|l|}{ House density } \\
\hline Healthy ( $\geq 8 \mathrm{~m}^{2} /$ person) & $24(54.5)$ & $54(61.4)$ & 1.32 & $0.64-2.75$ & 0.453 \\
\hline Not-healthy $\left(<8 \mathrm{~m}^{2} /\right.$ person $)$ & $20(45.5)$ & $34(38.6)$ & & & \\
\hline \multicolumn{6}{|l|}{ Smoke exposure } \\
\hline Good & $22(50.0)$ & $61(69.3)$ & 2.26 & $1.07-4.76$ & 0.032 \\
\hline Poor & $22(50.0)$ & $27(30.7)$ & & & \\
\hline \multicolumn{6}{|l|}{ Access to clean water } \\
\hline Yes & $14(31.8)$ & $40(45.5)$ & 1.79 & $0.83-3.82$ & 0.135 \\
\hline No & $30(68.2)$ & $48(54.5)$ & & & \\
\hline
\end{tabular}


Table 2 Crude OR and comparison between cases and controls

\begin{tabular}{|c|c|c|c|c|c|}
\hline Variables & Cases & Controls & Crude OR & $95 \% \mathrm{Cl}$ & p value \\
\hline \multicolumn{6}{|c|}{ Health care at first episode of illness } \\
\hline Health facilities & $21(47.7)$ & $72(81.8)$ & 4.93 & $2.21-10.99$ & 0.000 \\
\hline Non-health facilities & $23(52.3)$ & $16(18.2)$ & & & \\
\hline \multicolumn{6}{|c|}{ Number of days before accessing health facilities } \\
\hline Mean \pm SD & $3.27 \pm 1.32$ & $2.24 \pm 0,84$ & 2.45 & $1.66-3.61$ & 0.000 \\
\hline \multicolumn{6}{|l|}{ Frequency of illnesses } \\
\hline Low & $18(40.9)$ & $64(72.7)$ & 3.85 & $1.79-8.26$ & 0.001 \\
\hline High & $26(59.1)$ & $24(27.3)$ & & & \\
\hline
\end{tabular}

Table 3 Adjusted odd ratio for risk factor of severe pneumonia among children

\begin{tabular}{|c|c|c|c|}
\hline Variables & Adjusted OR & $95 \% \mathrm{Cl}$ & p value \\
\hline Delayed access to healthcare facilities & 2.15 & $1.39-3.32$ & 0.001 \\
\hline Non-health facilities at the first episode of illness & 4.02 & $1.53-10.61$ & 0.005 \\
\hline $\begin{array}{l}\text { Frequency of illnesses of more than four times over the last } \\
\text { six months }\end{array}$ & 5.45 & 2.13-13.96 & 0.000 \\
\hline
\end{tabular}

\section{DISCUSSION}

This study found that delayed access to healthcare facilities, children who did not access healthcare services, and frequent acute respiratory infections over the last six months increase the risk of severe pneumonia among children. This study revealed that children with delayed access to treatment or healthcare facilities were 2.15 times more likely to develop severe pneumonia when compared to those who promptly access healthcare services. This finding is relatively similar with other study conducted in West Kenya which found that children with delayed access to healthcare were 2.3 times more likely to develop severe pneumonia when compared to those who immediately seek for health services. ${ }^{9}$

Children who did not access health services at the first episode of illness were 4.02 times more likely to develop severe pneumonia. This finding is consistent with other studies in Kenya and Serang - West Jawa, which found that children presented with pneumonia who received treatment at the healthcare facilities were less likely to develop severe pneumonia. ${ }^{9,11}$ This present study confirmed that education level and knowledge of mother were not associated with severity of pneumonia, however there was an association between delayed access to health care facilities and low education level $(p=0.832)$ and poor level of knowledge $(p<0.000)$. This indicates that education and knowledge of mothers are indirectly associated with severe pneumonia among children. A study conducted in Makasar showed that delayed access to treatment is associated to the lack of knowledge of mothers on pneumonia and persistent perception that pneumonia is not a life-threatening illness, leading to delayed access to treatment or healthcare services. ${ }^{12}$

This present study showed that children with frequent illnesses were 5.45 times more likely to develop severe pneumonia. This might also be related to children nutritional status. Indeed, this study confirms that there was a significant association between nutritional status and frequency of illnesses among children $(p=0.028)$. Other study in Denpasar also found that frequency of illnesses among children increased risk of pneumonia by 10.14 times. $^{6}$

\section{CONCLUSION}

Delayed access to treatment, did not access healthcare facilities at the first episode of illness and frequency of acute respiratory infections are associated to severe pneumonia among children aged 12-59 months.

\section{ACKNOWLEDGEMENT}

We would like to thank the Director of Sanglah General Hospital Denpasar, the Head of Paediatric Department of Faculty of Medicine Udayana University/Sanglah General Hospital Denpasar, the Head of Pulmonology Unit, Department of Paediatric Faculty of Medicine Udayana University/ Sanglah General Hospital Denpasar, and all head of community health centres in Denpasar City, who had supported this study. 


\section{REFERENCES}

1. UNICEF. Pneumonia: The Forgotten killer of Children. September 2006. Geneva 27, Switzerland; 2006.

2. Ministry of Health of Indonesia. 2010. Buletin Jendela Epidemiologi. Jakarta; 2010; 3.

3. Ministry of Health of Indonesia. Basic Health Survey 2013. Jakarta, Badan Penelitian Pengembangan Kesehatan Kementerian Kesehatan RI; 2014.

4. Bali Province Health Office. Profil Dinas Kesehatan Provinsi Bali Tahun 2014. [Bali Province Health Profile 2014]. Denpasar, Dinas Kesehatan Provinsi Bali; 2014.

5. Scott J.Anthohy G, Brooks W.Abdullah, Peiris J.S. Malik, Holtzman Douglas, and Mulholland E.Kim, 2008, Pneumonia research to reduce childhood mortality in the develoving world. The journal of clinical investigation; $2008 ; 116(4)$.

6. Yudiastuti ENK, Sawitri AAS, Wirawan DN, 2015. Durasi pemberian ASI eksklusif, lingkungan fisik dan kondisi rumah sebagai faktor risiko pneumonia pada balita di Puskesmas II Denpasar Selatan [Duration of breastfeeding, physical environments, and house conditions as risk factors for pneumonia among children in South Denpasar II Community Health Centre], Public Health and Preventive Medicine Archive; 2015; 3(2).

7. Wonodi CB, Knoll MD, Feikin DR, Deluca AN, et al. 2012. Evaluation of risk factors for severe pneumonia in children: the pneumonia etiology research for child health study. Clinical Infectious Diseases; 2012: 54(2).

8. Jackson S, Mathews KH, Pulanic D, Falconer R, Rudan I, Campbell H, Nair H, 2013. Risk Factors For Severe Acute Lower Respiratory Infections in Children a Systematic Review and Meta Analysis, Croat Med Journal; 2013; 54:110-21
9. Onyango D, Kikuvi G, Amukoye E, Omolo O. Risk Factors of Severe Pneumonia Among Children Aged 2-59 Months in Western Kenya: A Case Control Study. Pan Africal Medical Journal; 2012.

10. WHO. Pocket book of hospital care for children second edition: guidelines for management of common childhood illness; 2013.

11. Hendarwan H. Faktor-faktor yang Berhubungan dengan Perilaku Ibu Balita dalam Pencarian Pengobatan Pada Kasus-Kasus Balita dengan Gejala Pneumonia di Kabupaten Serang [Factors associated to health seeking behaviours of mothers with children presenting pneumonia symptoms in Serang District]. Media Litbang Kesehatan; 2005; 15(3).

12. Mokoginta D, Arsin A, Sidik D. Faktor Risiko Kejadian Pneumonia pada Anak Balita di Wilayah Kerja Puskesmas Sudiang Kota Makasar [Risk factors of pneumonia among children in Sudiang Community Health Centre, Makasar City], Makasar, Bagian Epidemiologi FKM Universitas Hasanuddin; 2012.

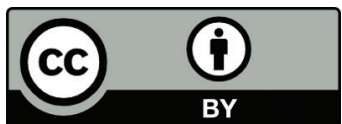

This work is licensed under a Creative Commons Attribution 